Materiales de Construcción

Vol. 69, Issue 334, April-June 2019, e184

ISSN-L: $0465-2746$

https://doi.org/10.3989/mc.2019.01418

\title{
Impact of twisting high-performance polyethylene fibre bundle reinforcements on the mechanical characteristics of high-strength concrete
}

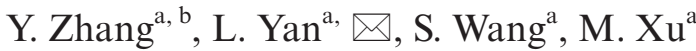 \\ a. College of Basic Education, National University of Defence Technology, (Changsha, China) \\ b. Centre for Structural Engineering and Informatics, Faculty of Engineering, \\ University of Nottingham, University Park, (Nottingham, UK) \\ \lhyan555@hotmail.com
}

Received 3 February 2018

Accepted 11 September 2018

Available on line 15 March 2019

\begin{abstract}
The quasi-static and dynamic mechanical behaviours of the concrete reinforced by twisting ultra-high molecular weight polyethylene (UHMWPE) fibre bundles with different volume fractions have been investigated. It was indicated that the improved mixing methodology and fibre geometry guaranteed the uniform distribution of fibres in concrete matrix. The UHMWPE fibres significantly enhanced the splitting tensile strength and residual compressive strength of concrete. The discussions on the key property parameters showed that the UHMWPE fibre reinforced concrete behaved tougher than the plain concrete. Owing to the more uniform distribution of fibres and higher bonding strength at fibre/matrix interface, the UHMWPE fibre with improved geometry enhanced the quasi-static splitting tensile strength and compressive strength of concrete more significantly than the other fibres. The dynamic compression tests demonstrated that the UHMWPE fibre reinforced concrete had considerable strain rate dependency. The bonding between fibres and concrete matrix contributed to the strength enhancement under low strain-rate compression.
\end{abstract}

KEYWORDS: High performance concrete; Workability; Fibre reinforcement; Mechanical properties; Bond resistance

Citation/Citar como: Zhang, y.; Yan, L.; Wang, S.; Xu, M. (2019) Impact of twisting high-performance polyethylene fibre bundle reinforcements on the mechanical characteristics of high-strength concrete. Mater. Construcc. 69 [334], e184 https://doi.org/10.3989/mc.2019.01418

RESUMEN: Impacto del refuerzo de fibra de polietileno de alto rendimiento torsionada en las características mecánicas del hormigón de alta resistencia. Se han investigado los comportamientos mecánicos cuasi-estáticos y dinámicos de un hormigón reforzado por haces de fibra torsionadas de polietileno de ultra alto peso molecular (UHMWPE) con diferentes fracciones de volumen. Se demostró la mejora en la metodología de la mezcla y la geometría de las fibras que garantizaban una distribución más uniforme de las mismas en el hormigón. Las fibras UHMWPE mejoraron significantemente la resistencia a la tracción y la resistencia residual a la compresión del hormigón. Los resultados muestran que el hormigón reforzado con fibras UHMWPE presentó un comportamiento resistente mejor que el hormigón sin fibras. Debido a la distribución más uniforme de las fibras y a la mayor fuerza de unión en la interfaz fibras/matriz, las fibras UHMWPE con geometría mejorada lograron una mayor resistencia a la tracción y compresión del hormigón de manera más significativa que otras fibras. Las pruebas de compresión dinámica demostraron que el hormigón con fibras UHMWPE tenía una considerable dependencia en la velocidad de tensión. La unión entre fibras y la matriz del hormigón contribuyó a la mejora de la resistencia a bajas velocidades de tensión.

PALABRAS CLAVE: Hormigón de altas prestaciones; Trabajabilidad; Refuerzo de fibras; Propiedades mecánicas; Fuerza de enlace.

ORCID ID: Y. Zhang (https://orcid.org/0000-0001-7017-1620); L. Yan (https://orcid.org/0000-0002-9778-1960); S. Wang (https://orcid.org/0000-0002-6100-8909); M. Xu (https://orcid.org/0000-0002-7057-6772)

Copyright: (C) 2019 CSIC. This is an open-access article distributed under the terms of the Creative Commons Attribution 4.0 International (CC BY 4.0) License. 


\section{INTRODUCTION}

Fibre reinforced concrete has widely emerged in civil and defence constructions due to its significantly improved properties, such as high tensile strength, high toughness and excellent durability. The quasi-static and dynamic mechanical properties of the concretes reinforced by a variety of fibres have been investigated extensively (1-11). With the increase of terrorist attacks and regional conflicts, more threats from blast and ballistic impacts may give rise to severe damage to concrete constructions. Hence, it is urgent to develop the concrete reinforced by high-performance fibres that not only possess good quasi-static mechanical properties but also have excellent impact resistance.

Ultra-high molecular weight polyethylene (UHMWPE) is a type of thermoplastic polyolefin and is made of long chains of polyethylene that align in the same orientation. The extremely long molecule chains contribute to the high strength of the UHMWPE. Moreover, UHMWPE is highly resistant to corrosive chemicals and abrasion, and has low moisture absorption. Based on these, UHMWPE fibre is manufactured to be a kind of high-performance flexible fibre with high tensile strength, low density and stable performance. This fibre has the anisotropic property as it is governed by the strong sp3 C-C bond in longitudinal direction while it is governed by the weak van der Waals interaction in the radial direction. The UHMWPE fibre has similar axial tensile strength to carbon fibre, but higher failure strain than carbon fibre (12). The quasi-static and dynamic mechanical properties of UHMWPE fibre and fibre-reinforced epoxy resin composites have been investigated, see (13-17) for details. It is reported that the UHMWPE fibre is low strain-rate dependent (17). Under soft foam impact (simulating blast impact) and ballistic impact, the UHMWPE fibre reinforced composites exhibited better resistance than the carbon fibre reinforced composites and stainless steel panel with the same areal density $(12,18)$. The UHMWPE fibre composite has been broadly used in vehicle and airplane applications as a lightweight and soft armour system. Hence, the concrete reinforced by the highperformance UHMWPE fibres should have better impact resistance than the concrete reinforced by other synthetics fibres. Some studies performed on the mechanical behaviour as well as explosive resistance of UHMWPE fibre reinforced concrete have demonstrated the advantages of this kind of fibre concrete (19-21).

The mechanical performance of fibre reinforced concrete is not only dependent on the strengths of concrete matrix and fibres, but also the interfacial bonding strength between them. Higher bonding strength can be achieved by optimizing the geometries of fibres. Simoes et al. (3) investigated the effect of steel fibre geometry on the tensile strength of the concrete. They pointed out that the concrete reinforced by 2D hooked shaped ending fibres had higher tensile strength than that reinforced by 1D straight ending fibres, and the tensile strength of concrete increased with the diameter and length of fibres. Xu et al. (22) reported that the concrete reinforced by 3D spiral steel fibre provided better dynamic resistance and energy absorption capacity than the concrete reinforced by 2D steel fibres (e.g. hooked, flattened and undulated fibres). This is due to the better internal confinement and bonding between spiral fibres and concrete matrix. As the UHMWPE fibres has low coefficient of friction, the bonding strength between unprocessed fibres and concrete matrix is limited. Thus, the UHMWPE fibres with high tensile strength are more likely to fail with pulling out rather than fibre fracture. In addition, this type of flexible fibre is easy to be intertwined, leading to an uneven distribution and significant defect . Li et al. (19) also reported the high volume fraction $(2.5 \%)$ of the UHMWPE fibre without being processed in that study may lead to the uneven distribution and large cluster of the fibres in concrete.

It has been reported that the fibre reinforced concrete is a typical strain rate sensitivity material (23-25), and the rate sensitivity under dynamic compression were dependent on the shapes of fibres (22). In addition, the dynamic constitutive model of concrete can provide a guidance for structural design. However, the study on the dynamic compressive constitutive model of UHMWPE fibre reinforced concrete has not been reported, which may limits the applications of this high-performance fibre reinforced concrete. Hence, the study on the dynamic compressive response of the concrete reinforced by UHMWPE fibres is also required.

In the present study, we develop the concrete reinforced by the twisting high-performance UHMWPE fibres with improved geometry. This kind of fibre is expected to be distributed more uniformly in concrete matrix and provide better bonding at fibre/ matrix interface, which may further improve the mechanical properties of concrete. We aim to gain insight into the quasi-static and dynamic mechanical behaviours of this fibre reinforced concrete systematically, and compare with the concretes reinforced by unprocessed UHMWPE fibre and the other fibres. The compressive responses and failure mechanisms of the twisting UHMWPE fibre concrete under quasi-static and dynamic loading are investigated to provide a guidance for the application of this fibre reinforced concrete. The preparing procedure for more uniform distribution of fibres and higher bonding strength of fibre/matrix interface has also been optimised. The outline of this paper is as follows. Section 2 presents the materials and preparation process for achieving excellent 
workability of the UHMWPE fibre reinforced concrete. The protocols for quasi-static splitting tension and compression tests as well as the dynamic compression tests through the SHPB setup have been explained in Section 3. In Section 4, the experimental results are discussed.

\section{MATERIALS AND PREPARATION}

\subsection{Materials and mix proportion}

In the present study, the Portland cement of specific surface area $4120 \mathrm{~cm}^{2} / \mathrm{g}$ was employed. Gravel with consistent grading size of $5-10 \mathrm{~mm}$ and fineness modulus of 6.5 was used as the coarse aggregate, and the river sand with density of $2.68 \mathrm{~g} / \mathrm{cm}^{3}$, grading size of $0.6-2.0 \mathrm{~mm}$ and fineness modulus of 2.5 was used as the fine aggregate. The silica fume of diameter $0.1-0.3 \mu \mathrm{m}$ and specific surface area $300000 \mathrm{~cm}^{2} / \mathrm{g}$ had $98 \%$ percent of $\mathrm{SiO}_{2}$. In order to achieve expected workability of the fibre reinforced concrete, the naphthalene based superplasticizer was mixed in the concrete. The ZTX99-400D type twisting UHMWPE fibre bundles were used as the reinforcements of concrete. The image of twisting fibre bundles is shown in Figure 1 (a), and the image as well as sketch of the single fibre bundle are shown in Figure 1 (b). The image of unprocessed UHMWPE fibres for reinforcing concrete (26) is also shown to characterise the difference of fibre geometries, see Figure 1 (c). Each twisting fibre bundle consisted of 400 single fibres which were twisted together. The twisting treatment contributed to a large diameter and a rough surface that increases the friction between fibres and concrete matrix. Moreover, the fibre bundle is more likely to be distributed uniformly in concrete without cluster than the single monofilament. The physical and mechanical properties of the UHMWPE fibre are summarized in Table 1.

UHMWPE fibre reinforced concretes with four different fibre volume fractions (FVF) of $0.3 \%$, $0.5 \%, 0.7 \%, 1.0 \%$, designated as U3, U5, U7, U10 for quasi-static tests and HU3, HU5, HU7, HU10 for dynamic compression tests, respectively, have been manufactured. The corresponding plain concrete specimens for quasi-static and dynamic tests designated as U0 and HU0 was prepared to compare with the fibre reinforced concretes. For the five types of fibre reinforced concretes, the mix proportions of cement, gravel, sand, silica fume, superplasticizer and water in concretes were all 547, 936, $615,57.5,12$ and $185 \mathrm{~kg} / \mathrm{m}^{3}$, respectively, as shown in Table 2. The proportions of the UHMWPE fibre mixed in the concrete are indicated in Table 3.

\subsection{Preparation of concrete specimens}

It is suggested that the dry fine particles should be added before adding water and superplasticizer $(27,28)$. It is due to the fact that the fine particles are easier to separate aggregates when the particles are dry. Figure 2 (a) illustrates an improved mixing methodology of the UHMWPE fibre concrete. This

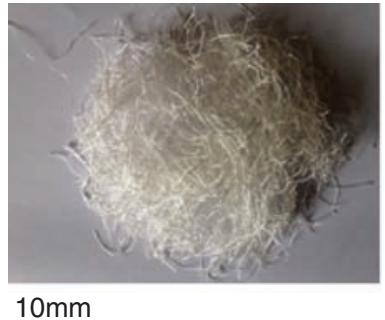

(a)

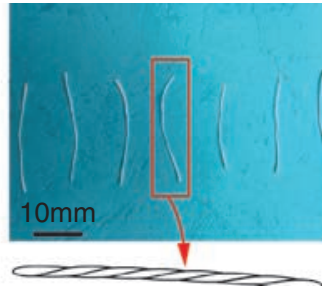

$10 \mathrm{~mm}$

(b)

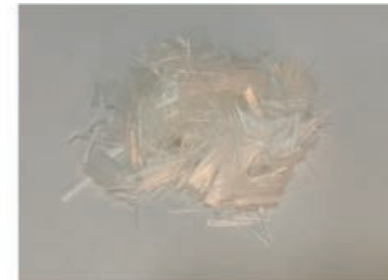

$10 \mathrm{~mm}$

(c)

FIGURE 1. (a) Image of twisting UHMWPE fibre bundle and (b) image and sketch of single twisting UHMWPE fibre bundle. (c) Unprocessed UHMWPE fibres.

TABLE 1. Physical and mechanical properties of UHMWPE fibre

\begin{tabular}{lcccc}
\hline $\begin{array}{l}\text { Diameter } \\
(\boldsymbol{\mu m})\end{array}$ & $\begin{array}{c}\text { Length } \\
(\mathbf{m m})\end{array}$ & $\begin{array}{c}\text { Density } \\
\left(\mathbf{g} \cdot \mathbf{m}^{-3}\right)\end{array}$ & $\begin{array}{c}\text { Axial Tensile strength } \\
(\mathbf{G P a})\end{array}$ & $\begin{array}{c}\text { Transverse tensile } \\
\text { strength }(\mathbf{G P a})\end{array}$ \\
\hline $20 \sim 50$ & 30 & 0.97 & 3.0 & 0.03 \\
\hline $\begin{array}{l}\text { Axial compressive } \\
\text { strength }(\mathbf{G P a})\end{array}$ & $\begin{array}{c}\text { Transverse } \\
\text { compressive strength }(\mathbf{G P a})\end{array}$ & $\begin{array}{c}\text { Axial tensile modulus } \\
(\mathbf{G P a})\end{array}$ & $\begin{array}{c}\text { Elongation } \\
(\mathbf{\%})\end{array}$ & $\begin{array}{c}\text { Friction coefficient } \\
(\text { yarn-on-yarn) }\end{array}$ \\
\hline 0.1 & 0.1 & 100 & $2.5 \sim 4.0$ & $0.05-0.07$ \\
\hline Melting temperature $\left({ }^{\circ} \mathbf{C}\right)$ & $\begin{array}{c}\text { Decomposition } \\
\text { temperature }\left({ }^{\circ} \mathbf{C}\right)\end{array}$ & Eye visibility & Water absorption & $\begin{array}{c}\text { Resistance to } \\
\text { most chemicals }\end{array}$ \\
\hline $144-152$ & $>300$ & Translucent & Negligible & Excellent \\
\hline
\end{tabular}


procedure can follow the three steps. First, cement, silica fume, gravel and sand were mixed together for $120 \mathrm{~s}$ with a vertical axis laboratory concrete mixer. Then, the twisting UHMWPE fibre bundles were added gradually to avoid the formation of chunks and mixed for additional 120 s. Finally, the mixed water and superplasticizer were added and kept mixing for $180 \mathrm{~s}$. The dry mixture has been shown in Figure 2 (b). The improved mixing methodology was based on a previous mixing methodology for preparing the UHMWPE fibre reinforced concrete (29). For the previous mixing methodology, the

TABLE 2. Mix proportions of plain concrete (Unit: $\mathrm{kg} \cdot \mathrm{m}^{-3}$ )

\begin{tabular}{lccccc}
\hline Water & Cement & Gravel & Sand & Silica fume & superplasticizer \\
\hline 185 & 547 & 936 & 615 & 57.5 & 12 \\
\hline
\end{tabular}

TABLE 3. Mix proportions of UHMWPE fibre and corresponding slump for fresh concrete

\begin{tabular}{lccccc}
\hline Index & U0 & U3 & U5 & U7 & U10 \\
\hline $\begin{array}{l}\text { UHMWPE fibre } \\
\left(\mathrm{kg} \cdot \mathrm{m}^{-3}\right)\end{array}$ & 0 & 2.91 & 4.85 & 6.79 & 9.70 \\
$\begin{array}{l}\text { Slump } \\
(\mathrm{mm})\end{array}$ & 205 & 120 & 90 & 65 & 45 \\
\hline
\end{tabular}

mixing time at each step was only $30 \mathrm{~s}$ which was too short to guarantee the good dispersion of fibres and hydration of cement. However, the improved mixing methodology solved the problem, and the fibre bundles distributed uniformly and no cluster occurred in concrete matrix. The slumps of concrete with different fibre volume fraction were measured according to the standard GB/T 50080-2002. The slumps of the fresh concretes were measured with a truncatedcone shaped mold of height $300 \mathrm{~mm}$, base diameter $100 \mathrm{~mm}$ and top diameter $200 \mathrm{~mm}$. The measured slump values are shown in Table 3. It indicated that the workability decreased with the increase of the UHMWPE fibre volume fraction. This is due to the fact that each twisting fibre bundle had space between single fibres and therefore locked a part of cement mortar from the matrix. The uniformly distributed UHMWPE fibres can be observed in the fresh concretes. Six cubic specimens of dimension $150 \times 150 \times 150 \mathrm{~mm}^{3}$, three prismatic specimens of dimension $300 \times 150 \times 150 \mathrm{~mm}^{3}$, and fifteen cylindrical specimens of diameter $92 \mathrm{~mm}$ and height $46 \mathrm{~mm}$ were moulded for each mixture. The volume of mixture per batch was $0.026 \mathrm{~m}^{3}$ that could manufacture six cubic specimens and around ten cylindrical specimens. The specimens were demoulded after $24 \mathrm{~h}$ casting and cured in a moist chamber at a
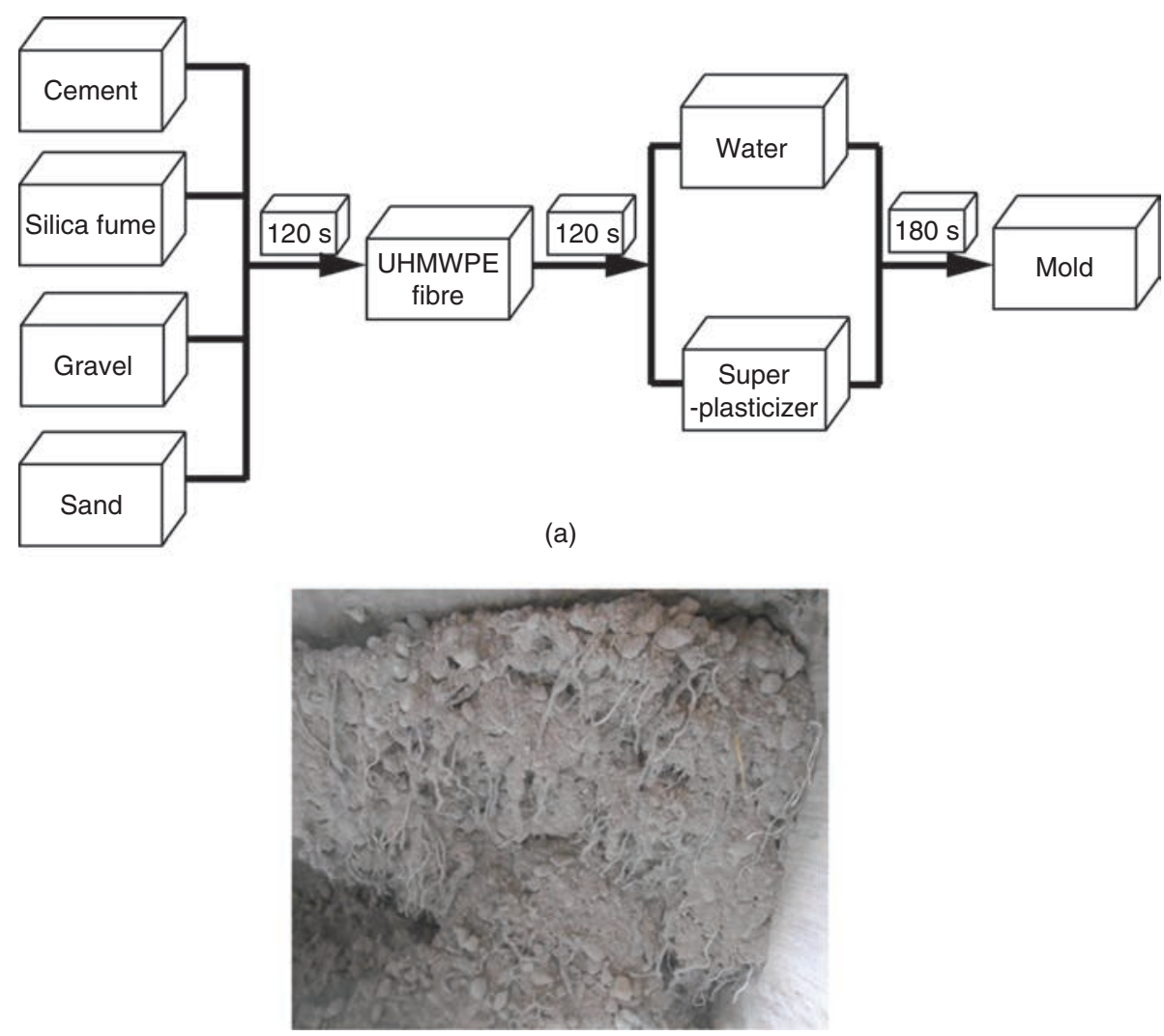

(b)

FIGURE 2. (a) Mixing procedure of the UHMWPE fibre reinforced concrete and (b) prepared dry mixture. 
temperature of $20 \pm 2{ }^{\circ} \mathrm{C}$ and $95 \%$ relative humidity until the age of testing. The cured cylindrical specimens were grinded to obtain flat surfaces.

\section{EXPERIMENTAL PROTOCOLS FOR UHMWPE FIBRE REINFORCED CONCRETE}

In order to characterise the mechanical behaviour of the fibre reinforced concretes, a serious of experimental measurements were performed. The design for quasi-static and dynamic testing has been summarized in Table 4.

\subsection{Quasi-static splitting tension and compression testing}

The splitting tensile strength and cubic uniaxial compressive strength were measured using $150 \times 150 \times 150 \mathrm{~mm}^{3}$ cubic specimens, both based on the methods described by standards GB/T 50081-2002. The compression test on $300 \times 150 \times 150 \mathrm{~mm}^{3}$ prismatic specimens was carried out in accordance with the standard GB/T 50081-2002 for measuring the prismatic uniaxial compressive strength, elastic modulus, poisson's ratio as well as the compressive toughness index. All the tests were conducted using an Instron 1346 testing machine at a constant loading rate of $1.0 \mathrm{~mm} / \mathrm{min}$. A linear variable differential transformer (LVDT) displacement transducer was used to measure the corresponding compressive strain of specimens. The LVDT had a displacement range of $51 \mathrm{~mm}$ and sensitivity $0.75 \mathrm{mV} / \mathrm{mm}$. In order to examine the poisson's ratio of the fibre reinforced concretes, two strain gauges of gauge length $5 \mathrm{~cm}$ and gauge factor 2.1 were attached centrally on the surface of the prismatic specimen, along and perpendicular to the loading direction, respectively. The strain gauges were connected to a DH3817 strain measurement system. The test on specimen for each mixture had four repeats. For the cylindrical specimens, the quasistatic compression test was conducted based on the ASTM C39 standards with loading rate $1.0 \mathrm{~mm} / \mathrm{min}$.

\subsection{Dynamic compression testing}

The dynamic compressive response of the UHMWPE fibre reinforced concrete was measured via the Split Hopkinson Pressure Bar (SHPB) setup (30), as shown in Figure 3. The photograph of setup and specimen at contact zone is also shown in this figure for clarity. As stated in Table 4, the cylindrical specimen for dynamic compression had height of $46 \mathrm{~mm}$ and diameter of $92 \mathrm{~mm}$. The concrete specimen was positioned between the input bar and output bar, and protected by a polycarbonate box of dimension $300 \times 300 \times 200 \mathrm{~mm}^{3}$ in case flying out of the fragments. The striker, input bar and output bar were all made from maraging steel of elastic modulus $210 \mathrm{GPa}$ and yield strength $1900 \mathrm{MPa}$, and had an identical diameter of $100 \mathrm{~mm}$, but lengths of $1.5 \mathrm{~m}$, $6.0 \mathrm{~m}$ and $4.0 \mathrm{~m}$, respectively. As the concrete material is not homogeneous due to the coarse aggregate with large diameter and irregular shape, the bars and specimens of large diameters was employed in the present study to reduce effect of coarse aggregate and the discrete of experimental data. In order to eliminate the axial inertia effect during test, the ratio of height to diameter of the specimen was designed to be 0.5 . The output bar was resisted at the distal end by an energy absorber. Both the input bar and output bar had two diametrically opposite $120 \Omega$ TML foil strain gauges of gauge length $2 \mathrm{~mm}$ in a half-Wheatstone bridge, located at the centre points of the two bars. The stress history was recorded by an oscilloscope as the voltage from the strain gauges changed. Pressurised nitrogen was employed to propel the striker to the velocities in the range of $5 \leq \mathrm{v}_{0} \leq 20 \mathrm{~ms}^{-1}$. The initial velocity of striker was measured by two laser gates located at the muzzle

TABLE 4. Summary of quasi-static and dynamic testing design

\begin{tabular}{|c|c|c|c|c|c|}
\hline & \multicolumn{4}{|c|}{ Quasi-static test } & \multirow[b]{2}{*}{$\begin{array}{c}\text { Dynamic } \\
\text { compression }\end{array}$} \\
\hline & Split tension & Cubic compression & $\begin{array}{c}\text { Prismatic } \\
\text { compression }\end{array}$ & $\begin{array}{c}\text { Cylindrical } \\
\text { compression }\end{array}$ & \\
\hline $\begin{array}{l}\text { Specimen } \\
\text { size }\left(\mathrm{mm}^{3}\right)\end{array}$ & $150 \times 150 \times 150$ & $150 \times 150 \times 150$ & $300 \times 150 \times 150$ & $\begin{array}{c}\Phi 92 \mathrm{~mm} \\
\text { Height } 46 \mathrm{~mm}\end{array}$ & $\begin{array}{c}\Phi 92 \mathrm{~mm} \\
\text { Height } 46 \mathrm{~mm}\end{array}$ \\
\hline Apparatus & Instron 1346 & Instron 1346 & Instron 1346 & Instron 1346 & SHPB \\
\hline Strain rate $\left(\mathrm{s}^{-1}\right)$ & $10^{-3}$ & $10^{-3}$ & $10^{-3}$ & $10^{-3}$ & $140 \sim 255$ \\
\hline Test standard & $\begin{array}{c}\text { GB/T } \\
50081-2002 \\
\end{array}$ & $\begin{array}{c}\mathrm{GB} / \mathrm{T} \\
50081-2002 \\
\end{array}$ & $\begin{array}{c}\mathrm{GB} / \mathrm{T} \\
50081-2002 \\
\end{array}$ & ASTM C39 & N/A \\
\hline $\begin{array}{l}\text { Measured } \\
\text { mechanical } \\
\text { properties }\end{array}$ & Tensile strength & $\begin{array}{l}\text { Cubic compressive } \\
\text { strength }\end{array}$ & $\begin{array}{l}\text { Prismatic compressive strength, } \\
\text { residual compressive strength, } \\
\text { poisson's ratio, elastic modulus, } \\
\text { compressive toughness index }\end{array}$ & $\begin{array}{l}\text { To compare } \\
\text { with dynamic } \\
\text { compressive } \\
\text { response }\end{array}$ & $\begin{array}{l}\text { Compressive strength, } \\
\text { dynamic increase factor } \\
\text { (DIF), Elastic modulus } \\
\text { increase factor }\left(F_{\mathrm{EM}}\right)\end{array}$ \\
\hline
\end{tabular}




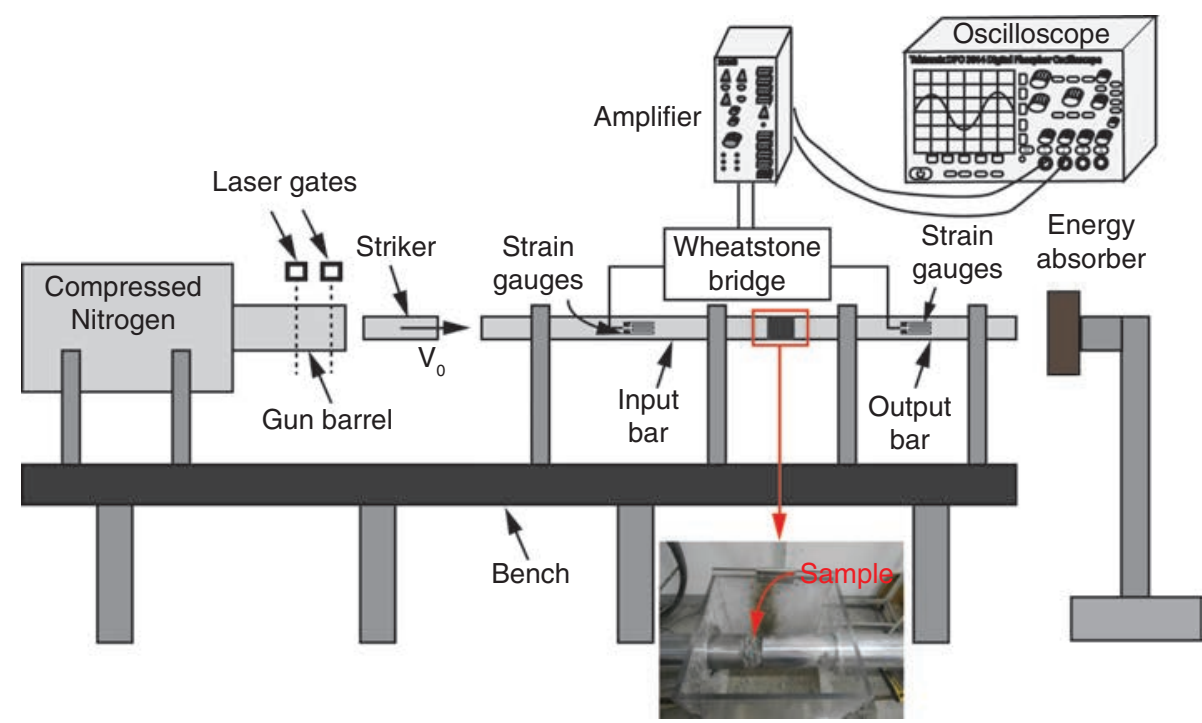

FIgure 3. Sketch of Split Hopkinson Pressure Bar (SHPB) setup employed in dynamic compression test.

of the gun barrel. The Photron FASTCAM SA5 high speed camera was used to measure the deformation process of UHMWPE fibre reinforced concrete under dynamic compression, and also confirm the striker velocity measured by laser gates. The frame rate and exposure time were typically 30,000 fps and $8 \mu \mathrm{s}$, respectively.

\section{RESULTS AND DISCUSSION}

\subsection{Quasi-static uniaxial tension and compression}

\subsubsection{Damage modes and failure mechanisms}

The comparison of damage modes between the plain concrete and fibre reinforced concrete of FVF $1.0 \%$ under splitting tension, cubic compression and prismatic compression has been shown in Figure 4. Apparently, the damage modes of the twisting UHMWPE fibre reinforced concrete were different from those of plain concrete whether in splitting tension test or compression test.

The prismatic compressive stress-strain relations of the plain concrete as well as UHMWPE fibre reinforced concretes are shown in Figure 5. To illustrate the failure mechanism of the fibre reinforced concrete, the compressive stress-strain relation of fibre reinforced concrete can be divided into four stages, and the representative deformation of the specimen of FVF $0.3 \%$ at each stage is shown in Figs. 6 (a)-(d), respectively.

(1) Stage I: Compacting (Figure 6 (a)). In the initial compression stage, the closure of pores and gaps in the concrete resulted in more dense interaction between fibre reinforcements and the concrete matrix. The specimen had a small deformation and there is no observable damage at this stage.
Fibre reinforced concrete $\left(V_{f}=1.0 \%\right)$

(a)

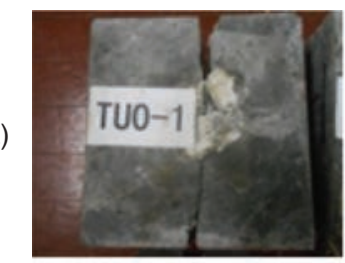

(b)
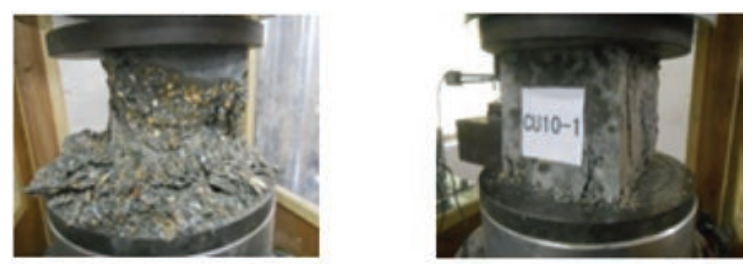

(c)
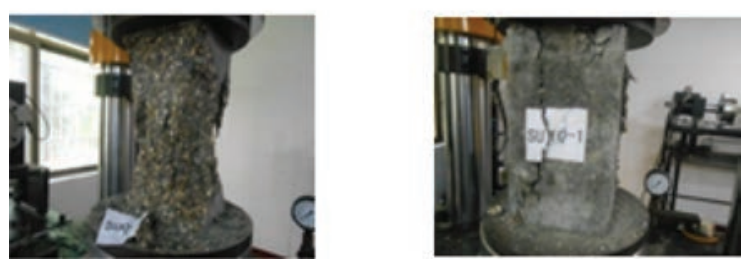

FIGURE 4. The damage mode comparisons of the plain concrete and UHMWPE fibre reinforced concrete $\left(V_{\mathrm{f}}=1.0 \%\right)$ under (a) splitting tension, (b) uniaxial cubic compression and (c) prismatic compression, respectively. Here, $V_{\mathrm{f}}$ represents the fibre volume fraction, the same below.

(2) Stage II: Micro-crack propagation (Figure 6 (b)). The micro-cracks began to develop at the weak locations in the concrete specimen when the loading exceeded the cohesive force between the concrete compositions. As the cracks were tiny, UHMWPE fibres didn't play a significant role in resisting the crack growth at this stage. This stage was linear 
(a)

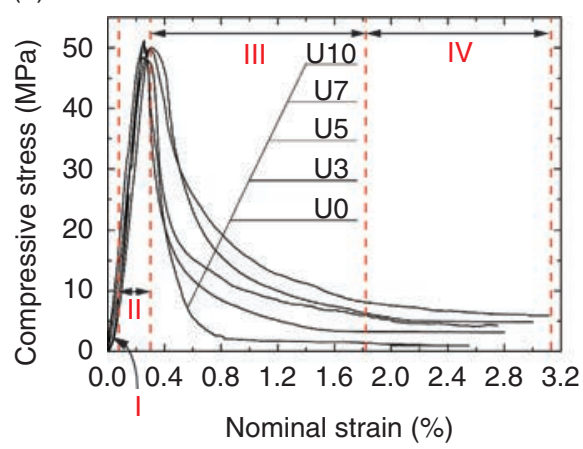

(b)

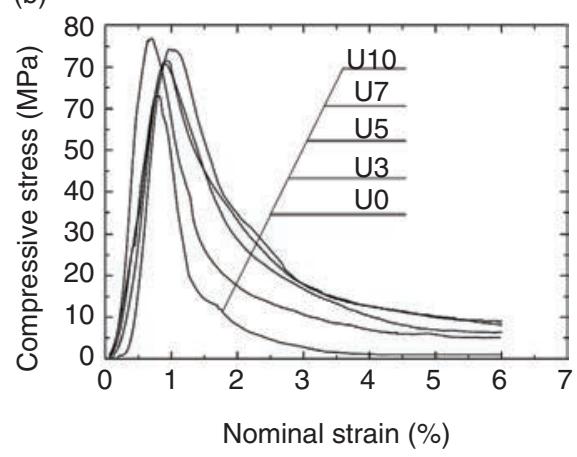

FIGURE 5. (a) Uniaxial prismatic and (b) cubic compressive stress-strain curves of the UHMWPE fibre reinforced concretes.

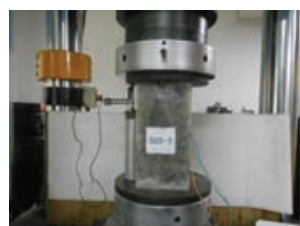

(a) Stage

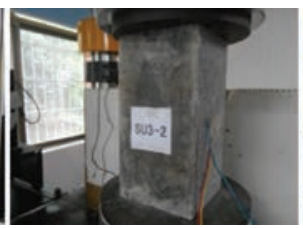

(b) Stage II

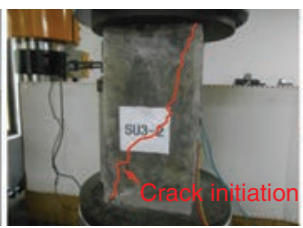

(c) Stage III

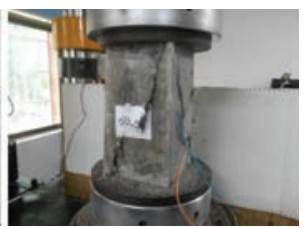

(d) Stage IV

FIGURE 6. The representative images at each compressive deformation stage of the UHMWPE fibre reinforced concrete $\left(V_{\mathrm{f}}=0.3 \%\right)$ shown in Figure 5 .

TABLE 5. Quasi-static tensile and compressive strengths of the UHMWPE fibre reinforced concretes

\begin{tabular}{lcccccccc}
\hline Index & $\begin{array}{c}\sigma_{t} \\
(\mathbf{M P a})\end{array}$ & $\begin{array}{c}\text { Standard } \\
\text { deviation } \\
(\mathbf{M P a})\end{array}$ & $\begin{array}{c}\sigma_{c} \\
(\mathbf{M P a})\end{array}$ & $\begin{array}{c}\text { Standard } \\
\text { deviation } \\
(\mathbf{M P a})\end{array}$ & $\begin{array}{c}\sigma_{c}^{\prime} \\
\mathbf{( M P a )}\end{array}$ & $\begin{array}{c}\text { Standard } \\
\text { deviation } \\
(\mathbf{M P a})\end{array}$ & $\begin{array}{c}\sigma_{r c}^{\prime} \\
(\mathbf{M P a})\end{array}$ & $\begin{array}{c}\text { Standard } \\
\text { deviation } \\
(\mathbf{M P a})\end{array}$ \\
\hline U0 & 3.55 & 0.28 & 68.0 & 4.21 & 53.2 & 3.20 & 0.94 & 0.059 \\
U3 & 5.23 & 0.37 & 78.0 & 5.73 & 52.9 & 2.97 & 3.10 & 0.024 \\
U5 & 5.44 & 0.40 & 72.9 & 4.88 & 47.3 & 3.30 & 4.23 & 0.016 \\
U7 & 5.58 & 0.33 & 72.7 & 4.16 & 49.2 & 2.79 & 4.86 & 0.032 \\
U10 & 6.34 & 0.42 & 75.1 & 5.16 & 50.7 & 2.88 & 5.90 & 0.035 \\
\hline
\end{tabular}

elastic, and the micro-cracks had a negligible effect on the compressive stress-strain relation.

(3) Stage III: Long crack growth and through (Figure 6 (c)). The cracks developed to be longer and wider with the increase of the deformation of specimen. However, the bridging and cohesion between fibres and concrete matrix contributed to the transformation and redistribution of the stress in specimen. The cracks promoted the development of the cracking surfaces which resulted in the further sharp decrease of the compressive stress.

(4) Stage IV: Residual strength (Figure 6 (d)). The horizontal expansion of the specimen indicated the excellent ductile behaviour of the UHMWPE fibre reinforced concrete. The fibre reinforced concrete still keeping a better integrity and possessing higher residual compressive strength than the plain concrete.

The compressive response of the twisting UHMWPE fibre reinforced cubic concrete specimen is shown in Figure 5 (b) to compare with that of prismatic concrete specimen. It indicated that the cubic specimens had higher compressive strength and failure strain than prismatic specimens. This is due to the more significant lateral constraint of cubic concrete specimen whose height is less than the prismatic specimen. The constraint enhanced the compressive strength and delayed the failure of concrete specimen.

\subsubsection{Splitting tensile strength and uniaxial compressive strength}

The average splitting tensile strength $\sigma_{t}$, cubic compressive strength $\sigma_{c}$, prismatic compressive strength $\sigma_{c}^{\prime}$, residual compressive strength $\sigma_{r c}^{\prime}$ and the corresponding standard deviation of the UHMWPE fibre reinforced concrete have been presented in Table 5. The ratios of the peak splitting tensile strength, cubic compressive strength and prismatic compressive strength of the fibre reinforced concrete specimens with varied FVFs to those of the 


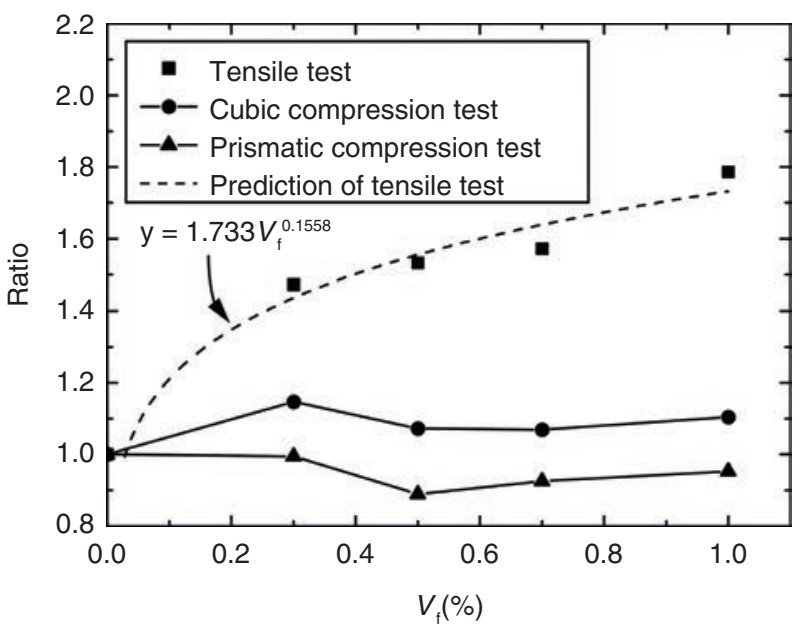

FIGURE 7. The ratios of peak splitting tensile strength, uniaxial cubic compressive strength, prismatic compressive strength of the UHMWPE fibre reinforced concrete specimens to those of the corresponding plain concrete specimens as a function of $V_{\mathrm{f}}$.

corresponding plain concrete specimens are given in Figure 7. The prediction represents the fitting of experimental measurements.

Compared to the plain concrete, the splitting tensile strengths of the fibre reinforced concretes had a significant improvement with the increase of FVF. The ratio was 1.47 at low fibre volume fraction, i.e. $0.3 \%$, and the ratio reached to 1.79 at higher fibre volume fraction of $1.0 \%$. The enhancement resulted from the excellent bonding strength between the UHMMWPE fibre bundles and concrete matrix, which delayed the formation of cracks in specimens, and higher fibre volume fraction contributes to higher bonding strength.

The cubic and prismatic compressive strengths of the fibre reinforced concretes in Table 5 are approximately $70 \mathrm{MPa}$ and $50 \mathrm{MPa}$, respectively. The UHMWPE fibre reinforcement didn't enhance the peak compressive strength of concrete significantly, and even slightly decreased the strength of the specimens under prismatic compression. For the four fibre volume fractions varied from $0.3 \%$ to $1.0 \%$, the concrete of FVF $0.3 \%$ obtained the highest compressive strength, whereas the concrete of FVF $0.5 \%$ had lowest compressive strength, the strength increased slightly at higher FVF until the FVF of $1.0 \%$. The results can be explained by following analysis. The UHMWPE fibre reinforcement filled the pores in the concrete at low FVF of $0.3 \%$ and enhanced the compressive strength of the specimen. The extra fibre leaded to conglobation at higher FVF of $0.5 \%$, this can be regarded as flaws which decreased the compressive strength of the concrete. Though the flaws were introduced with the increase of the fibre volume fraction (FVF $>0.5 \%)$, the more addition of UHMWPE fibres of high tensile strength and high modulus resisted the failure

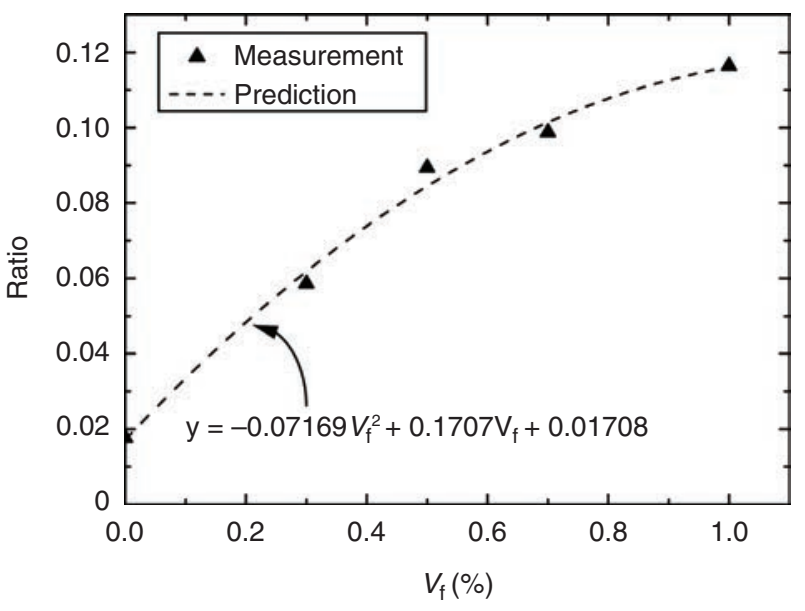

FIGURE 8. The ratio of residual compressive strength of UHMWPE fibre reinforced concrete to the peak compressive strength of the corresponding fibre reinforced concrete specimen as a function of $V_{\mathrm{f}}$

TABLE 6. Key parameter measurements of UHMWPE fibre reinforced concrete

\begin{tabular}{lcccccc}
\hline Index & $\begin{array}{c}\boldsymbol{E}_{c} \\
(\mathbf{G P a})\end{array}$ & $\boldsymbol{\mu}$ & $\boldsymbol{\varepsilon}_{m}$ & $\eta_{c 3.0}$ & $\eta_{c 5.5}$ & $\eta_{c 15.5}$ \\
\hline U0 & 34.78 & 0.21 & $2.5 \times 10^{-3}$ & 3.54 & 3.87 & 4.59 \\
U3 & 32.63 & 0.23 & $2.5 \times 10^{-3}$ & 3.72 & 4.77 & 6.41 \\
U5 & 29.60 & 0.26 & $2.6 \times 10^{-3}$ & 4.29 & 5.96 & 9.37 \\
U7 & 28.66 & 0.27 & $3.0 \times 10^{-3}$ & 5.11 & 6.95 & 9.38 \\
U10 & 28.15 & 0.30 & $3.1 \times 10^{-3}$ & 5.16 & 7.48 & 11.59 \\
\hline
\end{tabular}

of cracking surface and improved the compressive strength of the concrete specimen slightly.

Residual compressive strength is the constant stress of the prismatic concrete specimen at Stage IV that was described in Section 4.1. Figure 8 illustrates the ratio of the residual compressive strength of the fibre reinforced concrete to the peak compressive strength of the corresponding prismatic specimen as a function of FVF. The residual compressive strength increased almost linearly with the increase of FVF. Compared to the plain concrete, the residual compressive strength of the fibre reinforced concrete of FVF $0.3 \%$ enhanced 2.3 times and more than 5 times enhancement was achieved when the FVF was $1.0 \%$. Similar to the specimens in splitting tension test, the bonding strength between fibres and concrete matrix played a critical role in improving the post-cracking compressive strength of the concrete.

\subsubsection{The effect of FVF on the key properties of UHMWPE fibre reinforced concrete}

Table 6 indicates the measured key property parameters obtained from the plain concrete and UHMWPE fibre reinforced concrete. The trends for elastic modulus $E_{c}$, poisson's ratio $v$ and compressive toughness 


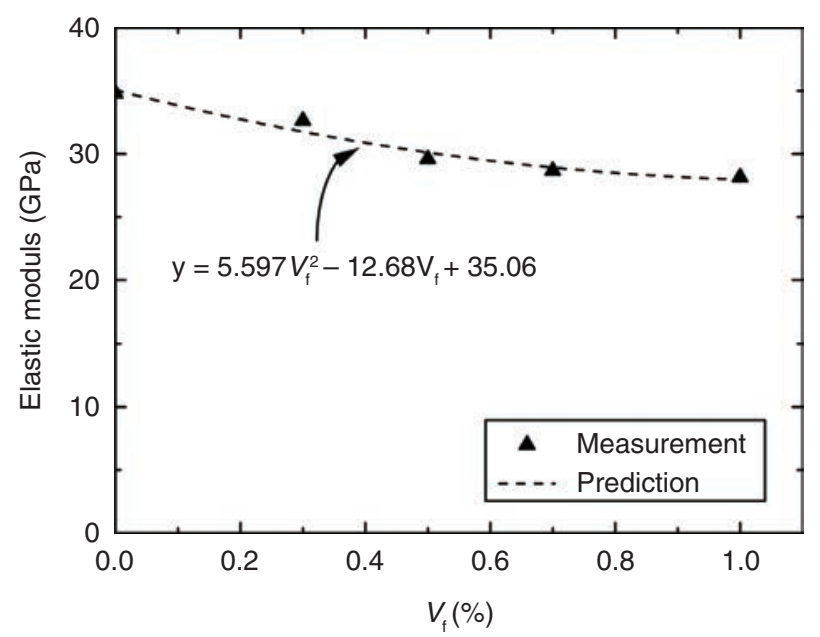

FIGURE 9. The elastic modulus of UHMWPE fibre reinforced concrete as a function of $V_{\mathrm{f}}$.

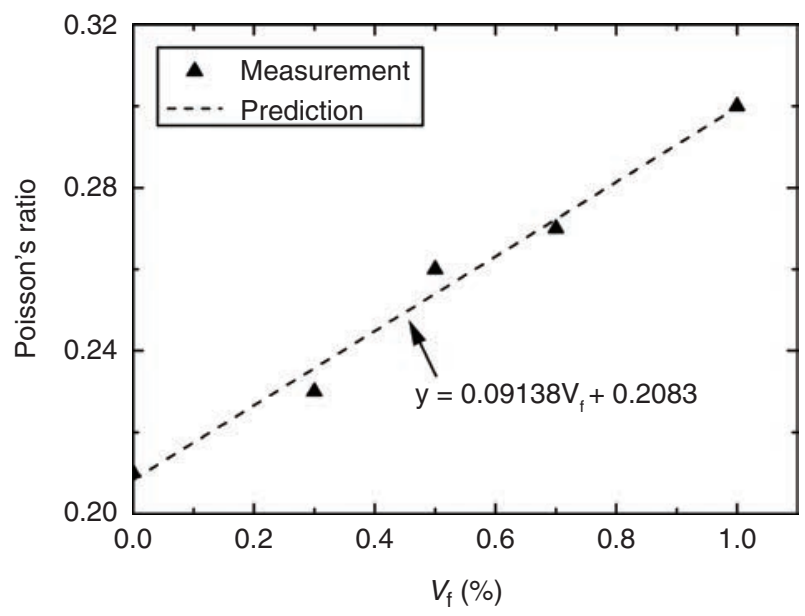

FIgURE 10. The poisson's ratio of UHMWPE fibre reinforced concrete as a function of $V_{\mathrm{f}}$.

index $\eta_{c}$ as a function of FVF have been plotted in Figure 9, Figure 10 and Figure 11, respectively. $\varepsilon_{m}$ is the nominal peak strain regarding to the peak compressive strength of the prismatic concrete specimen.

\section{(1) Elastic modulus}

Figure 9 shows the elastic modulus of the fibre reinforced concrete which was determined by the compressive response of the prismatic concrete specimen plotted in Figure 5. The elastic modulus of fibre reinforced concrete was lower than that of the plain concrete and decreased slightly when the FVF increased. This is due to the addition of the UHMWPE fibre reinforcements.

\section{(2) Poisson's ratio}

As shown in Figure 10, poisson's ratio increased linearly with the increase of FVF due to the ductile property of the fibre reinforced concrete. The reason

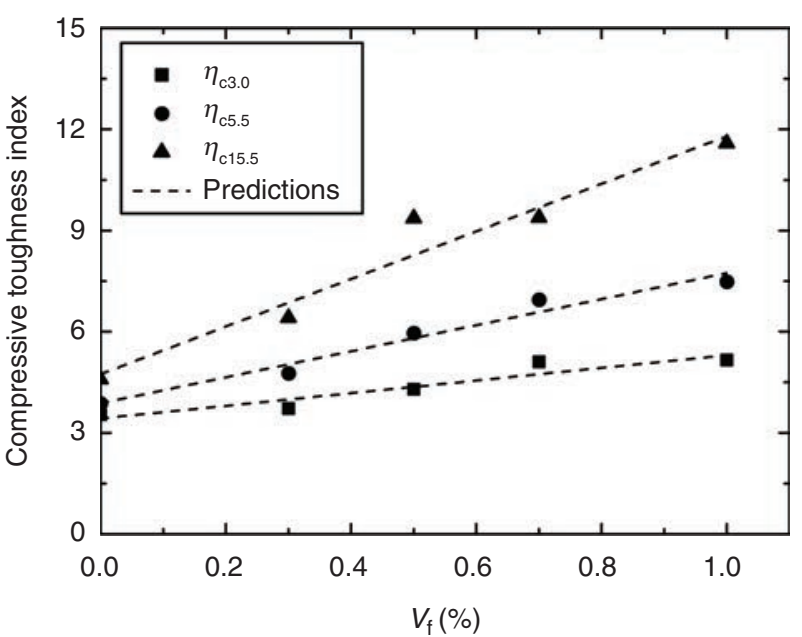

FIGURE 11. The compressive toughness index of UHMWPE fibre reinforced concrete as a function of $V_{\mathrm{f}}$.

for this result is consistent with the interpretation for the above measurements.

(3) Compressive toughness index

The toughness of the UHMWPE fibre reinforced concrete can be evaluated by compressive toughness index. First define the 0.85 times nominal peak strain $\mathcal{E}_{m}$ as the critical strain $\mathcal{E}_{c}$ The compressive toughness index $\eta_{c 3.0}, \eta_{c 5.5}, \eta_{c 15.5}$ can be defined as follow (31) eq [1].

$$
\begin{aligned}
& \eta_{c 3.0}=\frac{S_{\varepsilon_{3,0}}}{S_{\varepsilon_{c}}} \\
& \eta_{c 5.5}=\frac{S_{\varepsilon_{5.5}}}{S_{\varepsilon_{c}}} \\
& \eta_{c 15.5}=\frac{S_{\varepsilon_{15.5}}}{S_{\varepsilon_{c}}}
\end{aligned}
$$

where $S_{\varepsilon_{c}}, S_{\varepsilon_{30},}, S_{\varepsilon_{5,5}}, S_{\varepsilon_{155}}$ are the areas surrounded by the compressive stress-strain curves in Figure 5 when the maximum nominal strains are $\varepsilon_{c}, 3.0$ times $\mathcal{E}_{c}, 5.5$ times $\varepsilon_{c}$ and 15.5 times $\varepsilon_{c}$, respectively.

As shown in Figure 11, the compressive toughness index increased linearly with the increase of FVF. The index increased more significantly at larger deformation attributed to the considerable improvement of residual compressive strength of the UHMWPE fibre reinforced concrete. According to the evaluation, the $h_{c 15.5}$ of the fibre reinforced concrete of FVF 1.0\% was 2.53 times that of the plain concrete.

\subsection{Comparison between the current study and the concrete reinforced by other fibres}

In order to evaluate the advantages of the twisting UHMWPE fibre in reinforcing concrete, the 


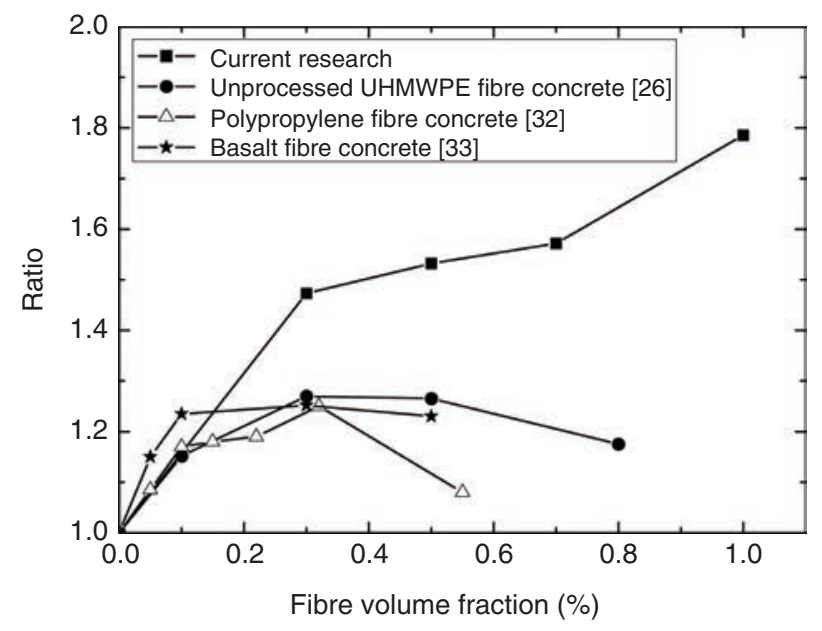

FIGURE 12. Splitting tensile strength Comparison between the current research and the other fibre reinforced concrete.

splitting tensile strength as well as uniaxial compressive strength of the twisting fibre concrete were compared with those of the concrete reinforced by other representative flexible fibres including unprocessed UHMWPE fibre (26), polypropylene fibre (32) and basalt fibre (33). For a reasonable comparison, these selected fibre reinforced concretes have similar compressive strengths and the fibre reinforcements have same or similar lengths. The lengths of unprocessed UHMWPE fibre, polypropylene fibre and basalt fibre are $30 \mathrm{~mm}, 19 \mathrm{~mm}$ and $22 \mathrm{~mm}$, respectively.

Figure 12 shows the ratio of splitting tensile strength of fibre concrete to that of plain concrete as a function of fibre volume fraction. At low fibre volume fraction (no more than $0.2 \%$ ), the splitting tensile strength of the concrete increased with the fibre volume fraction. When the fibre volume fraction was more than $0.2 \%$, the splitting tensile strength of the twisting UHMWPE fibre concrete kept increasing, whereas the strength enhancement for the concrete reinforced by other fibres kept a plateau level or even decreased.

Figure 13 shows the ratio of uniaxial compressive strength of fibre concrete to that of plain concrete as a function of fibre volume fraction. At low fibre volume fraction (no more than $0.1 \%$ ), the compressive strengths of all these fibre concretes were higher than the corresponding plain concretes. After that, the compressive strength of twisting UHMWPE fibre concrete decreased slightly with the increase of fibre volume fraction, but still higher than that of plain concrete. However, the compressive strengths of concrete reinforced by other fibres decreased more and were close to or even lower than that of plain concrete when the fibre volume fraction increased.

The results were explained that the high fibre volume fraction leaded to the cluster of fibres, which caused significant imperfections and prevent

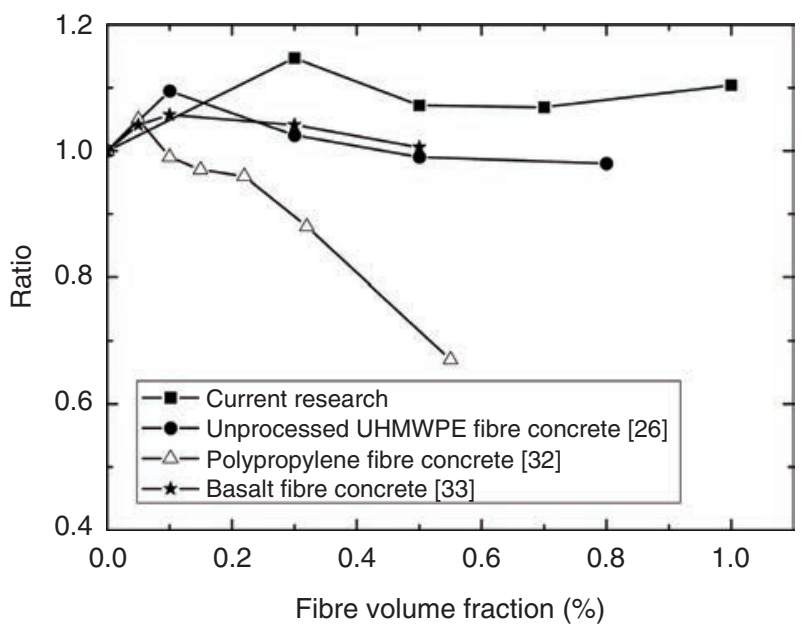

FIGURE 13. Uniaxial compressive strength Comparison between the current research and the other fibre reinforced concrete.

fibre from bonding tightly with concrete matrix. However, the twisting UHMWPE fibres could be distributed more uniformly at high fibre volume fraction due to the improved fibre geometry and mixing methodology. Hence, the twisting UHWPE fibres played a more positive role in bridging cracks and confining concrete deformation than the unprocessed UHMWPE fibres, polypropylene fibres and basalt fibres.

\subsection{Dynamic compression}

Since the twisting UHMWPE fibre reinforced concrete exhibits more excellent quasi-static mechanical properties than that reinforced by unprocessed UHMWPE fibres and other highperformance fibres, it is necessary to investigate its dynamic response for widening the applicability of this material.

Figure 14 shows the high-speed photography of the twisting UHMWPE fibre concrete specimens during dynamic compression. The longitudinal cracking in the specimen was observed at the initial compression stage, then the cracking developed when the specimen shortened, followed by the debris splashing when the bonding stress decreased significantly in the concrete. However, the cracking in the UHMWPE reinforced concrete specimens developed more slowly and created a smaller debris splashing area compared to the plain concrete specimen. Figs. 15 (a) and (b) show the damage modes of the UHMWPE fibre reinforced concretes after quasi-static compression and dynamic compression at strain rate of $\dot{\varepsilon}=175 \mathrm{~s}^{-1}$. The digits of 0,1 , 2,3 and 4 after dash represent the number of the strain rates applied, corresponding to $10^{-3} \mathrm{~s}^{-1}, 140 \mathrm{~s}^{-1}$, $175 \mathrm{~s}^{-1}, 200 \mathrm{~s}^{-1}$ and $255 \mathrm{~s}^{-1}$, respectively. It indicated that the UHMWPE fibre reinforced concrete kept 


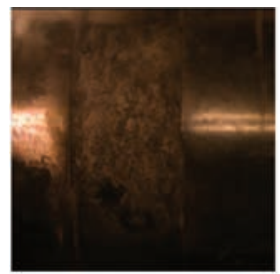

$\mathrm{t}=0.767 \mathrm{~ms}$

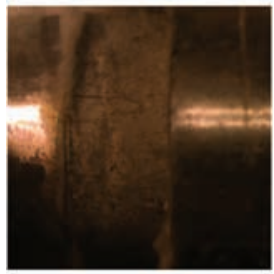

$\mathrm{t}=0.767 \mathrm{~ms}$

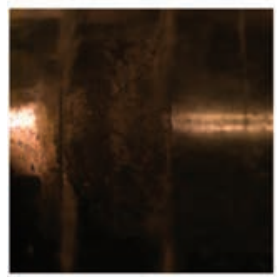

$\mathrm{t}=0.767 \mathrm{~ms}$

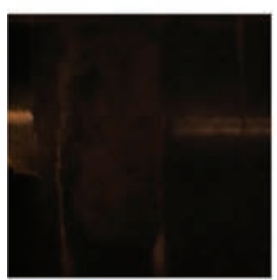

$\mathrm{t}=0.767 \mathrm{~ms}$

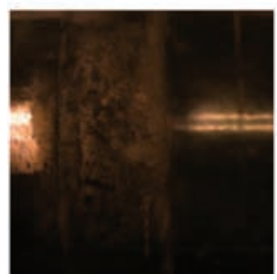

$\mathrm{t}=0.767 \mathrm{~ms}$

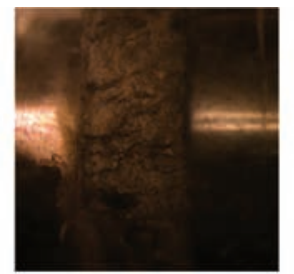

$\mathrm{t}=1.167 \mathrm{~ms}$

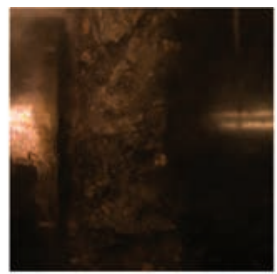

$\mathrm{t}=2.900 \mathrm{~ms}$

(a) $\mathrm{HUO}-2$

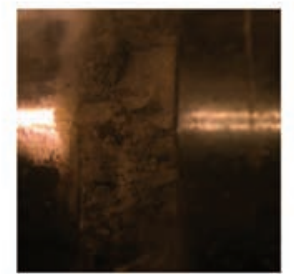

$\mathrm{t}=1.167 \mathrm{~ms}$

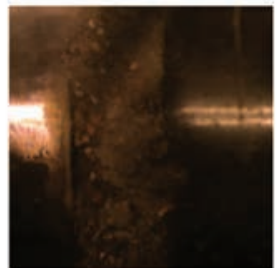

$\mathrm{t}=2.900 \mathrm{~ms}$

(b) HU3-2

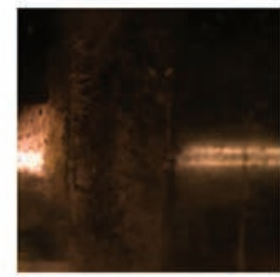

$\mathrm{t}=1.167 \mathrm{~ms}$

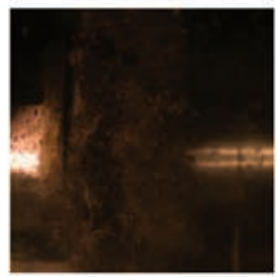

$\mathrm{t}=2.900 \mathrm{~ms}$

(c) HU5-2

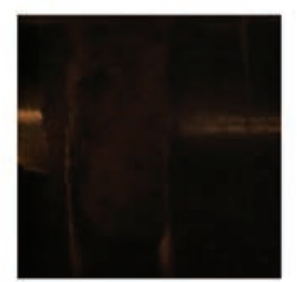

$\mathrm{t}=1.167 \mathrm{~ms}$

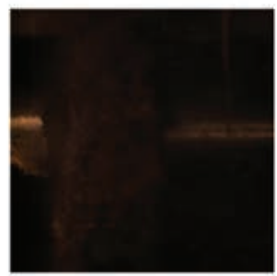

$\mathrm{t}=2.900 \mathrm{~ms}$

(d) HU7-2

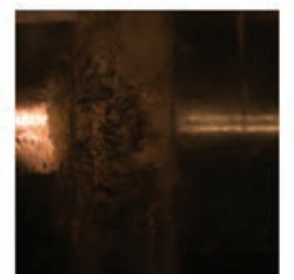

$\mathrm{t}=1.167 \mathrm{~ms}$

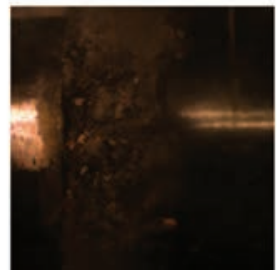

$\mathrm{t}=2.900 \mathrm{~ms}$

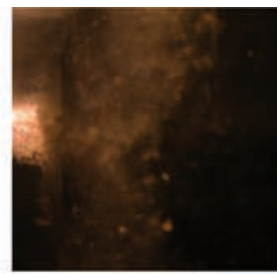

$\mathrm{t}=6.300 \mathrm{~ms}$

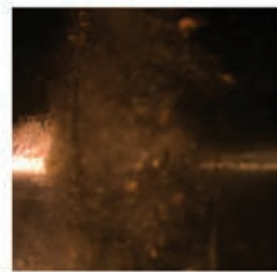

$\mathrm{t}=6.300 \mathrm{~ms}$

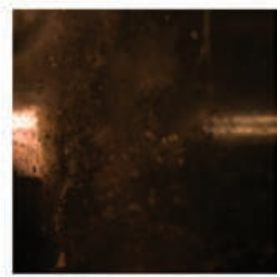

$\mathrm{t}=6.300 \mathrm{~ms}$

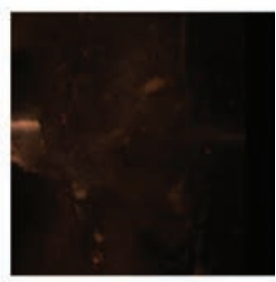

$\mathrm{t}=6.300 \mathrm{~ms}$

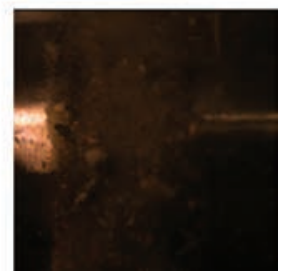

$\mathrm{t}=6.300 \mathrm{~ms}$

(e) HU10-2

FIGURE 14. Dynamic compressive deformation process of (a) plain concrete, (b) HU3, (c) HU5, (d) HU7 and (e) HU10 at strain rate of $175 \mathrm{~s}$ 
(a)

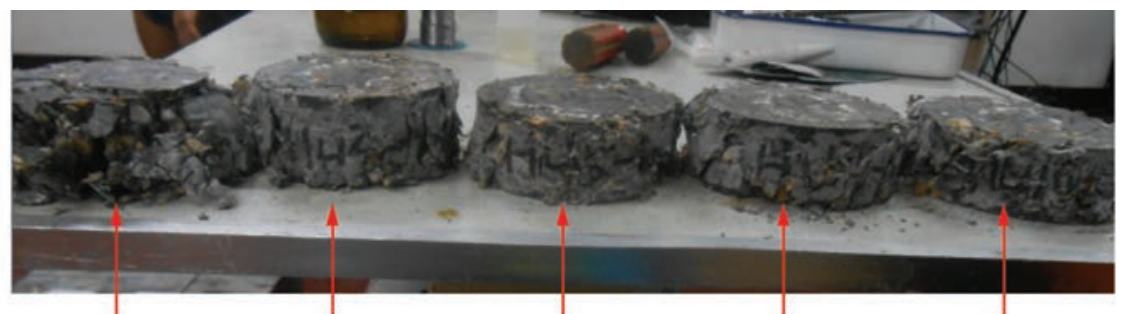

(b)

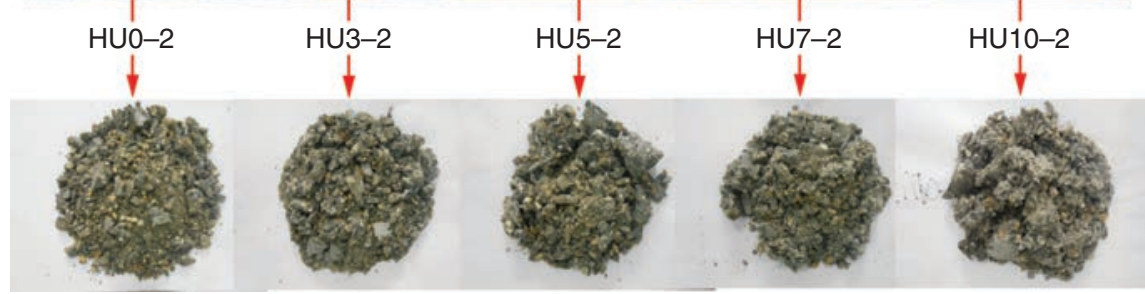

FIGURE 15. The damage modes of the UHMWPE fibre reinforced concretes under (a) quasi-static compression and (b) dynamic compression at strain rate of $\dot{\varepsilon}=175 \mathrm{~s}^{-1}$.

a better integrity than the plain concrete under quasi-static compression. For the dynamic compression, bigger broken concrete blocks were obtained with the increase of FVF due to the better bridging between the UHMWPE fibre reinforcements and concrete matrix. Hence, the bridging of fibres contributed to more excellent cracking resistance and strength enhancement.

The nominal compressive stress-strain relations of the UHMWPE fibre reinforced concretes at five strain rates ranging from $10^{-3} \mathrm{~s}^{-1}$ to $255 \mathrm{~s}^{-1}$ are shown in Figs. 16 (a)-(e). It is indicated that the quasi-static compressive strengths of the cylindrical UHMWPE fibre reinforced concrete specimens with different FVFs were similar, approximately $70 \mathrm{MPa}$. The dynamic compressive strengths of the plain concrete as well as the UHMWPE fibre reinforced concrete enhanced significantly with the increase of strain rate. An important index to evaluate the compressive resistance of material is energy absorption capacity that can be quantified by the area surrounded by stress-strain curve. For each fibre volume fraction, the energy absorption capacity of concrete increased with the increase of strain rate.

Dynamic increase factor (DIF), which was defined as the ratio of dynamic compressive strength to quasi-static compressive strength, was used to explain the strength enhancement: eq [2].

$$
f_{D I F}=\frac{\sigma_{c c d}}{\sigma_{c c}}
$$

Where $f_{D I F}$ is the dynamic increase factor (DIF), $\sigma_{c c d}$ and $\sigma_{c c}$ are the dynamic and quasi-static compressive strengths of the cylindrical UHMWPE fibre reinforced concrete specimens at the same FVF, respectively.

Figure 16(f) shows the DIF of the UHMWPE fibre reinforced concrete as a function of $\log \dot{\varepsilon}$. The DIF increased linearly with $\log \dot{\varepsilon}$. Compared to the plain concrete, the DIF of the twisting UHMWPE fibre reinforced concretes was higher but increased more slowly at low strain rates $\left(\dot{\varepsilon}=144 \mathrm{~s}^{-1}\right)$. This trend for the strength enhancement may due to the fact that the strain rate sensitivity of the concrete matrix played a dominate role, and the fibres provided constraint on enhancing the strength of specimen at low strain rates. However, the addition of fibre reduced the strain rate sensitivity of concrete slightly. For the UHMWPE fibre reinforced concrete under the same strain rate, the DIF of the HU5 and HU7 increased more significantly than those of the HU3 and HU10. In the range of the applied strain rates, the DIF of the UHMWPE fibre reinforced concretes with different FVFs ranged from 1.02 to 1.95 . The DIF prediction for the plain concrete of compressive strength 28 MPa-55MPa, proposed by Tedesco and Ross (24), is suggested as follow eq. [3] and shown in Figure 16 (f).

$$
f_{\text {DIF }}=0.758 \log \dot{\varepsilon}-0.289
$$

However, this prediction doesn't explain the trend of DIF for the currently researched plain concrete and UHMWPE fibre reinforced concrete well. This may due to the higher compressive strength of the specimen in the current research and the effect of the twisting UHMWPE fibre reinforcements.

The elastic modulus increase factor, $F_{E M}$, as a function of strain rate has been shown in Figure 17. $F_{E M}$ is defined as [4]

$$
F_{\mathrm{EM}}=\frac{E_{c c d}}{E_{c c}}
$$

where $E_{c c d}$ and $E_{c c}$ are the elastic modulus of the cylindrical UHMWPE fibre reinforced concrete specimens at the same FVF under dynamic and quasi-static compressions, respectively.

The $F_{E M}$ increased with the increase of strain rate, and more significantly at higher strain rates, 

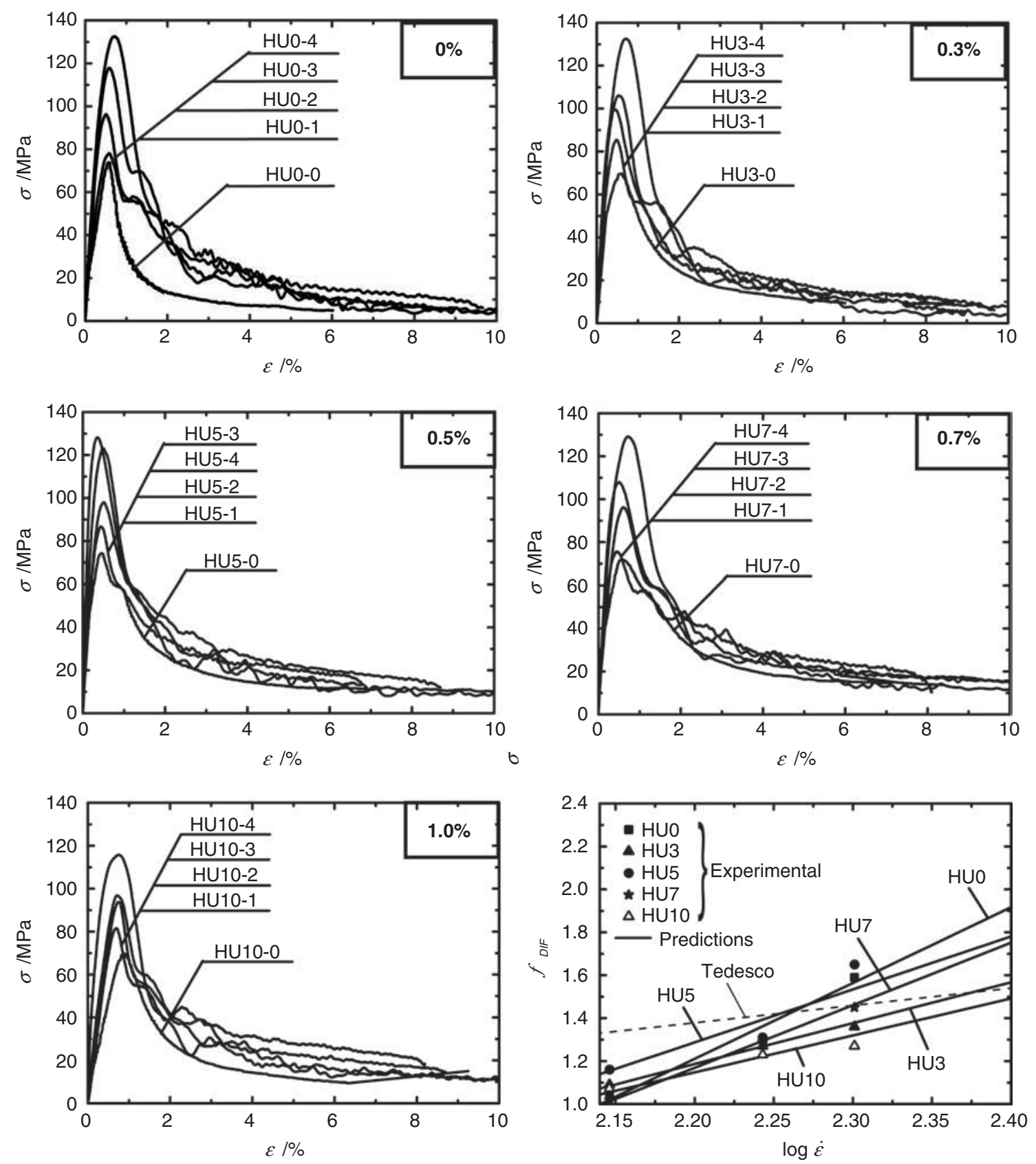

FIGURE 16. Nominal compressive stress-strain relations of UHMWPE fibre reinforced concretes of fibre volume fraction (a) $0 \%$, (b) $0.3 \%$, (c) $0.5 \%$, (d) $0.7 \%$, (e) $1.0 \%$ at five strain rates ranging from $10^{-3} \mathrm{~s}^{-1}$ to $255 \mathrm{~s}^{-1}$. (f) shows the dynamic increase factor (DIF) of UHMWPE fibre reinforced concrete as a function of $\log \dot{\varepsilon}$.

particularly for the HU5 and HU10. However, the $F_{E M}$ of the plain concrete increased slightly. Hence, it is concluded that the elastic modulus of UHMWPE fibre reinforced concrete has rate dependency.

\section{CONCLUSIONS}

The twisting high-performance UHMWPE fibre bundle with improved geometry was employed to reinforce concrete and expected to improve the mechanical properties of concrete. Based on this, both the quasi-static and dynamic tests of the concrete with varied fibre volume fraction from 0 to $1.0 \%$ have been conducted. The quasi-static splitting tensile and compressive strengths of this type of fibre concrete were compared with the concrete reinforced by other fibres. A Split Hopkinson Pressure Bar (SHPB) measurement setup was used for the dynamic compression test at strain rates of $140 \mathrm{~s}^{-1}$ to $255 \mathrm{~s}^{-1}$. 


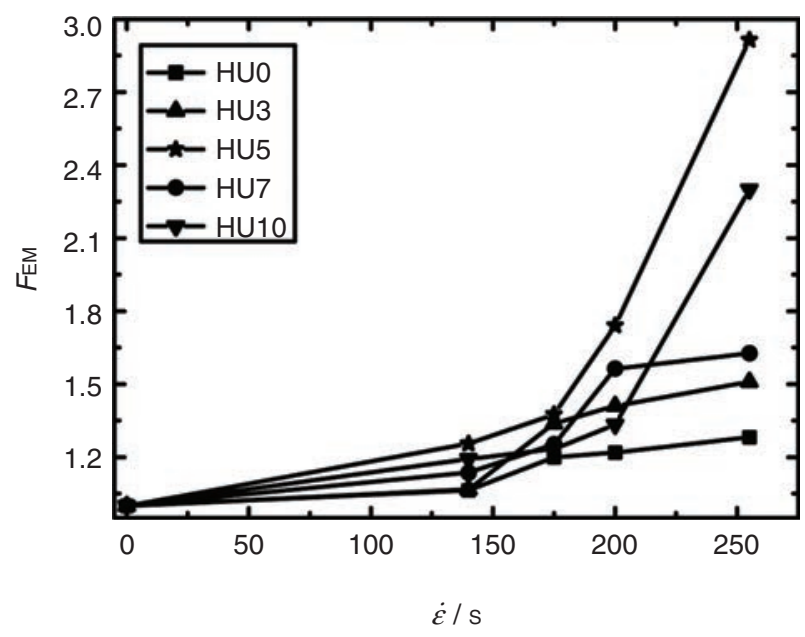

FIGURE 17. Elastic modulus increase factor $\left(F_{\mathrm{EM}}\right)$ of UHMWPE fibre reinforced concrete as a function of strain rate.

The improved preparation method increased the mixing time at each step that guaranteed the good workability of the twisting UHMWPE fibre reinforced concrete. The twisting UHMWPE fibre reinforcements improved the splitting tensile strength and residual compressive strength of the concrete significantly, e.g. $78.6 \%$ and $528 \%$ enhancement for the concrete of FVF 1.0\% compared with those of the plain concrete, respectively. In addition, the investigations into the key property parameters of fibre reinforced concrete, such as elastic modulus, poisson's ratio as well as compressive toughness index, suggest that the UHMWPE fibre reinforced concrete had a tougher behaviour than the plain concrete. By comparing with the concrete reinforced by other fibres, i.e. unprocessed UHMPWE fibre, polypropylene fibre and basalt fibre, it indicated that the twisting UHMWPE fibre bundle improved the splitting tensile strength and compressive strength of concrete more significantly, the improvement was more apparent at high fibre volume fraction. The superiority is due to the uniform distribution of twisting UHMWPE fibres in concrete matrix and high bonding strength at fibre/matric interface.

The addition of the UHMWPE fibres enhanced the impact resistance and energy absorption capacity of concrete. The strength enhancement of the twisting UHMWPE fibre reinforced concrete under dynamic compression was governed by the strain rate sensitivity of the concrete matrix. The bonding strength between fibre reinforcements and concrete matrix also enhanced the strength at low strain rates. In addition, the strain rate increased the elastic modulus of the UHMWPE fibre reinforced concretes. These findings can provide guidance for designing high-performance fibre reinforced concrete structures.

\section{ACKNOWLEDGEMENT}

The authors wish to acknowledge Hunan Zhongtai special equipment Ltd for supplying the ZTX99-400D twisting UHMWPE fibre bundles, and technical discussion facilitating the experimental programme.

\section{REFERENCES}

1. Song, P.S.; Hwang, S. (2004) Mechanical properties of high-strength steel fiber-reinforced concrete. Constr. Build. Mater. 18: 669-73. https://doi.org/10.1016/j. conbuildmat.2004.04.027

2. Hao, Y.; Hao, H. (2013) Dynamic compressive behaviour of spiral steel fibre reinforced concrete in split Hopkinson pressure bar tests. Constr. Build. Mater. 48: 521-32. https:// doi.org/10.1016/j.conbuildmat.2013.07.022

3. Simões, T.; Octávio, C.; Valença, J.; Costa, H.; Dias-daCosta, D.; Júlio, E. (2017) Influence of concrete strength and steel fibre geometry on the fibre/matrix interface. Compos. B. Eng. 122: 156-64. https://doi.org/10.1016/j. compositesb.2017.04.010

4. Choi, Y.; Yuan, R.L. (2005) Experimental relationship between splitting tensile strength and compressive strength of GFRC and PFRC. Cem. Concr. Res. 35: 1587-91. https:// doi.org/10.1016/j.cemconres.2004.09.010

5. Langlois, V.; Fiorio, B.; Beaucour, A.L.; Cabrillac, R.; Gouvenot, D. (2007) Experimental study of the mechanical behavior of continuous glass and carbon yarn-reinforced mortars. Constr. Build. Mater. 21: 198-210. https:// doi.org/10.1016/j.conbuildmat.2005.06.048

6. Dawood, E.T.; Ramli, M. (2011) High strength characteristics of cement mortar reinforced with hybrid fibres. Constr. Build. Mater. 25: 2240-7. https://doi.org/10.1016/j. conbuildmat.2010.11.008

7. Alberti, M.G.; Enfedaque, A.; Gálvez, J.C.; Cánovas, M.F.; Osorio, I.R. (2014) Polyolefin fiber-reinforced concrete enhanced with steel-hooked fibers in low proportions. Mater. Des. 60: 57-65. https://doi.org/10.1016/j. matdes.2014.03.050

8. Sim, J.; Park, C.; Moon, D.Y. (2005) Characteristics of basalt fiber as a strengthening material for concrete structures. Compos. B. Eng. 36: 504-12. https://doi.org/10.1016/j. compositesb.2005.02.002

9. Mastali, M.; Dalvand, A.; Sattarifard, A. (2017) The impact resistance and mechanical properties of the reinforced selfcompacting concrete incorporating recycled CFRP fiber with different lengths and dosages. Compos. B. Eng. 112: 74-92. https://doi.org/10.1016/j.compositesb.2016.12.029

10. Hannawi, K.; Bian, H.; Prince-Agbodjan, W.; Raghavan, B. (2016) Effect of different types of fibers on the microstructure and the mechanical behavior of Ultra-High Performance Fiber-Reinforced Concretes. Compos. B. Eng. 86: 214-20. https://doi.org/10.1016/j. compositesb.2015.09.059

11. Raoof, S.M.; Koutas, L.N.; Bournas, D.A. (2017) Textilereinforced mortar (TRM) versus fibre-reinforced polymers (FRP) in flexural strengthening of RC beams. Constr. Build. Mater. 151: 279-91. https://doi.org/10.1016/j. conbuildmat.2017.05.023

12. Karthikeyan, K.; Russell, B.P.; Fleck, N.A.; Wadley, H.N.G.; Deshpande, V.S. (2013) The effect of shear strength on the ballistic response of laminated composite plates. Eur. J. Mech. A. Solids. 42: 35-53. https://doi. org/10.1016/j.euromechsol.2013.04.002

13. Attwood, J.P.; Fleck, N.A.; Wadley, H.N.G.; Deshpande, V.S. (2015) The compressive response of ultra-high molecular weight polyethylene fibres and composites. Int. J. Solids. Struct. 71: 141-55. https://doi.org/10.1016/j. ijsolstr.2015.06.015

14. Attwood, J.P.; Khaderi, S.N.; Karthikeyan, K. (2014) The out-of-plane compressive response of Dyneema ${ }^{8}$ 
composites. J. Mech. Phys. Solids. 70: 200-26. https://doi. org/10.1016/j.jmps.2014.05.017

15. O'Masta, M.R.; Crayton, D.H.; Deshpande, V.S.; Wadley, H.N.G. (2015) Mechanisms of penetration in polyethylene reinforced cross-ply laminates. Int. J. Impact. Eng. 86: 24964. https://doi.org/10.1016/j.ijimpeng.2015.08.012

16. Chocron, S.; King, N.; Bigger, R.; Walker, J.D.; Heisserer, U.; van der Werff, H. (2013) Impacts and Waves in Dyneema ${ }^{\circledR}$ HB80 Strips and Laminates. Int. J. Appl. Mech. 80: 1-10. https://doi.org/10.1115/1.4023349

17. Russell, B.P.; Karthikeyan, K.; Deshpande, V.S.; Fleck, N.A. (2013) The high strain rate response of Ultra High Molecularweight Polyethylene: From fibre to laminate. Int. J. Impact. Eng. 60: 1-9. https://doi.org/10.1016/j.ijimpeng.2013.03.010

18. Karthikeyan, K.; Russell, B.P.; Fleck, N.A.; O'Masta, M.; Wadley, H.N.G.; Deshpande, V.S. (2013) The soft impact response of composite laminate beams. Int. J. Impact. Eng. 60: 24-36. https://doi.org/10.1016/j.ijimpeng.2013.04.002

19. Li, J; Wu, C.: Liu, Z.X. (2018) Comparative evaluation of steel wire mesh, steel fibre and high performance polyethylene fibre reinforced concrete slabs in blast tests. Thin-Walled. Struct. 126: 117-26. https://doi.org/10.1016/j.tws.2017.05.023

20. Li, L.; Yan, L.; Zhang, Y. (2015) Experiment research of UHMWPE fiber reinforced concrete under triaxial compression. International Conference on Applied Science and Engineering Innovation (ASEI 2015). 1847-52.

21. Zhang, Y.; Yan, L.; Zhu, L.; Zhang, S.; Li, L. (2014) Experiment research on mechanical properties and penetration performance of UHMWPE fiber concrete. $A d v$. Mater. Res. 989-994: 961-5. https://doi.org/10.4028/www. scientific.net/AMR.989-994.961

22. Xu, Z.; Hao, H.; Li, H.N. (2012) Experimental study of dynamic compressive properties of fibre reinforced concrete material with different fibres. Mater. Des. 33: 42-55. https://doi.org/10.1016/j.matdes.2011.07.004

23. Lok, T.S.; Asce, M.; Zhao, P.J. (2014) Impact response of steel fibre-reinforced concrete using a Split Hopkinson Pressure Bar. J. Mater. Civ. Eng. 16: 54-9. https://doi. org/10.1061/(ASCE)0899-1561(2004)16:1(54)
24. Tedesco, J.W.; Ross, C.A. (1998) Strain-Rate-Dependent Constitutive Equations for Concrete. J. Press. Vessel. Technol. 120: 398-405. https://doi.org/10.1115/1.2842350

25. Li, Q.M.; Meng, H. (2003) About the dynamic strength enhancement of concrete-like materials in a split Hopkinson pressure bar test. Int. J. Solids. Struct. 10: 34360. https://doi.org/10.1016/S0020-7683(02)00526-7

26. Yan, L.; Zhang, Y.; Zhu, L. (2014) Basic mechanical properties of ultra high molecular weight polyethylene fiber reinforced concrete. Journal of National University of Defense Technology. 36: 43-7.

27. Máca, P.; Sovják, R.; Konvalinka, P. (2014) Mix design of UHPFRC and its response to projectile impact. Int. J. Impact. Eng. 63: 158-63. https://doi.org/10.1016/j. ijimpeng.2013.08.003

28. Habel, K.; Gauvreau, P. (2008) Response of ultra-high performance fiber reinforced concrete (UHPFRC) to impact and static loading. Cem. Concr. Compos. 30: 93846. https://doi.org/10.1016/j.cemconcomp.2008.09.001

29. Lin, Z. (2013) Research on mechanical behaviors and antipenetration characteristics of UHMWPE fibre reinforced concrete. Changsha: National University of Defence Technology.

30. Su, Y.; Li, J.; Wu, C.; Wu, P.; Li, Z.X. (2016) Influences of nano-particles on dynamic strength of ultra-high performance concrete. Compos. B. Eng. 91: 595-609. https://doi. org/10.1016/j.compositesb.2016.01.044

31. Ji, B. (2011) Experimental study and numerical simulation on static and dynamic compressive behavior of 3-D braid steel fiber reinforced concrete. Nanjing, China: Nanjing University of Aeronautics and Astronautics.

32. Zhang, W. (2010) Experimental research of the mechanical properties of polypropylene fiber reinforced highstrength concrete. Taiyuan: Taiyuan University of Technology.

33. Jiang, C.; Fan, K.; Wu, F.; Chen, D. (2014) Experimental study on the mechanical properties and microstructure of chopped basalt fibre reinforced concrete. Mater. Des. 58 : 187-93. https://doi.org/10.1016/j.matdes.2014.01.056 
$16 \cdot$ Y. Zhang et al. 